\title{
The Communicative Orientation of English Language Teaching Classrooms in Moroccan Secondary Schools
}

\author{
Abderrahim El Karfa ${ }^{1}$ \\ ${ }^{1}$ Faculty of Letters and Human Sciences, Dhar Mehraz, Sidi Mohammed Ben Abdullah University, Fès, \\ Morocco \\ Correspondence: Abderrahim El Karfa, Faculty of Letters and Human Sciences, Dhar Mehraz, Sidi Mohammed \\ Ben Abdullah University, Fès, Morocco.
}

\author{
Received: August 28, 2019 Accepted: October 29, 2019 Online Published: October 31, 2019 \\ doi: 10.5539/elt.v12n11p97 URL: https://doi.org/10.5539/elt.v12n11p97
}

\begin{abstract}
The present paper addresses the issue of theory and practice in the implementation of the communicative approach in the context of English as a foreign language teaching in Morocco. It set to evaluate the communicative orientation of English language teaching classrooms in Moroccan secondary schools. This evaluation incorporates the investigation of the constraints imposed on teaching English for communicative purposes in this context. The results reveal the dominance of non-communicatively oriented practices and classrooms over their communicatively oriented counterparts. However, the dominance of communicative features in forty-one of the classes observed (34.16\%) is relatively high given the current state of communicative language teaching in Morocco and the constraints that were found to impede its implementation in this context. These constraints are related essentially to the foreign language context, the formal nature of the classroom environment, the traditional nature of students' personality traits and their conceptions of classroom participation and role-relationships, the nature of assessment procedures, lack of adequate and varied teaching materials and equipment, and the large size of classes. These findings suggest that English language teaching in Moroccan secondary schools has undergone important changes from the dominance of traditional and teacher-centred classrooms towards more communicative language teaching. They would also imply that the implementation of the communicative approach in foreign language contexts is not impossible, but rather feasible. To this end, this article presents some suggestions to enhance communicatively oriented attitudes and practices in English as a foreign language teaching classrooms in Morocco.
\end{abstract}

Keywords: communicative approach, communicative language teaching, Moroccan English education policy, the learner-centred approach, English language teaching, foreign language teaching

\section{Introduction}

In the history of second and foreign language teaching, various methods have been developed. These methods differ with respect to their theoretical assumptions about the nature of language and what knowledge of a language involves. Accordingly, they have different implications for second and foreign language teaching classrooms, namely the roles of learners and teachers, teaching activities and materials as well as classroom management patterns such as interaction and error treatment. Over all, a distinction is usually made between traditional methods such as the grammar-translation, the direct and the audio-lingual methods, which are generally described as teacher-centred and more recent methods such as the learner-centred and the communicative approaches, which are, generally, characterized as learning-learner-centred approaches. The present section deals with the principles and implications of the learner-centred and communicative approach and how the innovations they brought about have been conceived of in the context of English language education in Moroccan secondary schools.

\subsection{Principles of the Communicative Approach}

Communicative language teaching approaches have been developed to respond to a general concern with the socio-functional and communicative aspects of language, as well as recognition of the role of the learner as active participant in the process of teaching and learning. These innovations have been brought about under the influence of the developments made in the field of modern linguistics, particularly the Chomskyan mentalist theory of language and language acquisition and the sociolinguistic theory of Hymes and his notion of 
communicative competence. This concept has since then become the goal of second language teaching and learning within this perspective and a key term in the definition of these approaches and "a household word in second language research and teaching" (Brown, 1987: 198). To this end, these innovations were first taken up by syllabus designers whose first attempts in this respect resulted in the development of notional, functional, and situational syllabuses. However, Widdowson argues that "there is no such a thing as a communicative syllabus (1990: 130). He explains that "no syllabus, however conceived and designed, can produce a communicative competence which is crucially a methodological matter" (1990: 39-40).

The communicative approach holds that classroom communication is an integrated and complex process which is achieved through interactive language use and collaborative and cooperative negotiation of meaning and shared understanding between the participants in classroom interaction. For instance, Widdowson reports that "the pedagogic movement of the seventies and eighties that goes under the banner of CLT can be characterized not only by a novel concern for communication but by a different conception of the nature of communication from that which prevailed in the preceding era" (1990: 130). Advocates of this approach stress the role of learners' participation in classroom interactive communication in providing various opportunities for communicative language use and, therefore, for second language learning and acquisition. In this respect, Ellis stresses that "any second language learning that takes place must in some way result from the process of interaction the learners take part in" (1990: 91). Similarly, Van Lier explains that "the reason for focusing on participation is the assumption that it is in some way directly related to learning or at least to opportunities for learning" (1988: 92-93).

Proponents of the communicative approach assume that classroom communication should more or less approximate natural communication outside the classroom. For example, Ellis reports that "classroom L2 acquisition will be most successful if the environmental conditions which are to be found in naturalistic acquisition prevail" (1992: 37). In this context, Byrness proposes that "only by helping learners deal with authentic texts can we re-establish the connection the connection of language to its natural setting and purpose" (1987: 183). To this end, Littlewoods suggests various social interaction activities which "approximate more closely to the kind of communication situation encountered outside the classroom, where language is not only a functional instrument, but also a form of social behaviour" (1981: 43).

Although communicative language approaches are based on a "much more socially-sensitive view of language" (Brumfit, 1984: 25), it does not, and should not, be taken to mean a rejection of grammar. For example, Widdowson points out that "a communicative approach, properly conceive, does not involve the rejection of grammar. On the contrary, it involves recognising "its central mediating role in the use and learning of language" (1990:97). It holds that language structures and formal aspects are best acquired when learners are engaged in meaning-focused and message-oriented communicative language use. Hatch argues that "one learns to do conversation; one learns how to interact verbally and out of this interaction syntactic structures are developed" (1978: 404).

\subsection{Learner-centeredness}

Learner-centred approaches to language teaching and learning can be defined as "those which justify themselves in terms of concern for the learner" (Prabhu, 1984: 164). The focus within this perspective is not only on the linguistic achievements of learners, but also on their human and personal development. Similarly, Van Lier discusses the importance of learners' awareness of different aspects of their learning experience and the constraints that surround it and the resources available to them, for them to grow up as responsible, authentic, autonomous and independent learners. He extends the meaning of the concept of authenticity to include the characteristics of autonomy, independence, awareness and responsibility. He writes, "In personal authenticity, all the elements of awareness, autonomy, and authenticity come together. Authentic persons know what they are doing, and attend in relaxed or focused ways, in accordance with the demands of the situation. Authentic persons are also autonomous, in the sense of feeling responsible for their own actions, and able to deal with choices" (Van Lier, 1996: 144). In brief, language teaching within this new perspective is no longer meant to provide learners with a body of knowledge which they have to receive and consume, it is rather meant to develop in them a sense of independence and responsibility which are the educational long-term purposes of second language education.

The communicative approach is essentially learner-centred since it holds that "more classroom time is allotted for students to actively communicate with one another" (Johnson, 1995: 116). For example, Littlewood explains that "communicative teaching approaches leave the learner scope to contribute his own personality to the learning process. They also provide the teacher with scope to step out his didactic role in order to be a "human 
among humans" (1981: 94). This concern with the learner as a central agent in second and foreign language education is meant to develop their sense of responsibility and awareness of their learning, for as Littlewood explains: "Students should take responsibility for their own learning. This is both because all learning can in any case only be carried out by the students themselves and also because they need to develop the ability to continue learning after the end of their formal education" (1999: 71).This principle of communicative language teaching suggests that teaching activities and patterns of classroom communication and organisation that should prevail in a 'communicative' language teaching classroom are those which foster the learners' willingness to actively participate in the use of language for communicative purpose. In connection with this, Weaver and Cohen explain that "the philosophy of foreign language instruction has changed to one which is more interactive and communicative, and less static and teacher-centred" (1998: 66).

However, learners' willingness to participate actively in interactive classroom communication may be constrained by their personality characteristics and conceptions of classroom participation and organisation, and role relationships. Although learners' perceptions and expectations are certainly socially conditioned and deep-rooted in their previous formal and informal educational experiences, the classroom context would largely shape their reactions and attitudes towards the target language, teaching materials and practices. In this respect, Ouakrime explains that "the influence of the classroom context is no less important. A student's positive response to teaching techniques and materials [...] will largely affect his/her ability as an independent learner" Briendly, 1991:71). This suggests that learners' variables and needs should be considered, for if the learners, for example, "cannot transfer their learning strategies to the new situation, or the course content and methodology does not conform to their expectations, dissatisfaction may result" (1989: 74). Learner-centeredness holds that the effectiveness of an approach to second language teaching and learning depends on the extent to which it meets the learners' perceived needs.

\subsection{Implications}

The communicative approach has various implications for second and foreign language pedagogy. The most widely recognised pattern of classroom communication and organisation is student-student interaction in small group work and pair work activities. For example, Foster points out that "when interacting in small groups students talk more than they do in teacher-fronted activities [...] and that they have the opportunity to practice a greater variety of speech acts" (1998: 2). Similarly, Van Lier recommends these activities for their "major defining characteristics in terms of participation is that the learner is primary speaker" (1988: 173). More importantly, these activities help to create a stress-free and safe space in the classroom, which would be motivating for students to take part in classroom communication. For example, foster reports that "small group work in EFL classrooms [...] avoids the anxiety and self consciousness that prevents some students from speaking up in front of the whole class [...]. In sum, it can help to create a positive and relaxed learning environment." (1998: 1).

When such a pattern of classroom communication is established and maintained in second and foreign language classrooms, more opportunities are granted for learners: "to participate in meaning-focused communication, to perform a range of language functions, to participate in the negotiation of meaning, to engage in both planned and unplanned discourse, to assume different roles in their interaction, and finally to initiate, control the topic of discussion and self-select [when and how] to participate" (Johnson, 1995: 128). Along with this, Lightbown summarises the findings of many studies on group work and pair interaction where learners: "(1) are able to give each other FL/SL input and opportunities for interaction, (2) do not necessarily produce more errors than when they are interacting with the teacher, (3) can provide each other with fed back on error, in the form of clarification request and negotiation of meaning, and (4) benefit from the opportunity for more one-to-one conversation than they can get in a teacher-centred whole class environment" (Lightbown, 2000: 439).

Communicative language teaching has various implications for second and foreign language classroom activities and practices, the most important of which are problem-solving tasks, simulation and role play activities, reasoning gap and opinion gap exercises, and information gap activities, "through which the teacher can create an information gap and thus simulate simple patterns of communicative interaction. In each case [i.e., communicative activity] it is the overcoming of the information gap rather than the production of correct language that signals the success of performance". In this respect, "the focus of the activity is on meanings to be communicated rather than linguistic forms to be learnt" (Littlewood, 1981: 29). He points out that in our everyday language use, we normally focus our attention primarily on the meaning of what we say or hear, rather than on its linguistic form" Littlewood, 1981: 88). These activities are meaning-focused and learner-centred. As Nunan points out, "dills and the like rest power in the teacher, while communication tasks such as role play, problem solving tasks, and simulations give much more control to the learner" (1989: 86). 
The communicative approach also implies the use of more authentic teaching materials which could promote students' awareness and practice of different varieties of language that may encounter outside the classroom. To this end, "teaching materials should be suggestive rather than definitive" (Nunan, 1988: 99). To this end, the content should be presented in a way that promotes learners' interest and use of language in interactive communication, content which "is not only efficient in terms of their learning goals, but also more motivating" (Littlewood, 1981: 78). Teachers need to reconsider their error treatment practice and questioning behaviour. First, they need to assume a tolerant attitude towards learners' errors, which have to be considered as "a natural part of the process of language acquisition" (Brumfit, 1988: 6); otherwise, an extensive correction of learners' errors on the part of teachers is likely to restrict language for purposeful communication. For instance, (Littlewood, 1981: 91) suggests that "in communicative activities [...], the teacher must be aware of that excessive correction of errors will encourage learners to shift their focus from meanings to forms". Second, in order to motivate learners to use more exploratory and extended speech, the teacher needs to vary his questions with an emphasis on referential open-ended questions, which have been to elicit more extended, original and unpredictable utterances from learners" (e.g., Allen, Fröhlich, \& Spada, 1984).

\subsection{Communicative Language Teaching in Morocco}

English language teaching in Morocco has undergone some important changes with respect to the methodology of teaching, syllabus design and textbook writing since the 1980s. The most important aspect of this change has been an emerging concern with learner-centred communicative language teaching. The present subsection discusses the general principles on which the communicative approach to English language teaching in morocco is based (the official guidelines, 1994), since "there is likely to be a distinctive 'flavour' to communicative language teaching in Morocco" (Swales, 1993: 58). For example, Bendouqui (1996: 160) notes that "it was not until the late eighties, with the flourishing of communicative approach that, curriculum designers in our country came to assert the fact that ELT in Morocco is communicatively-oriented". Similarly, Kharraf and Messaoudi (1993: 99) emphasize this fact and state that "since the beginning of the eighties, EFL in Morocco has been moving towards a more communicative approach to language teaching".

The writers of the official guidelines state that the aim of ELT in Moroccan secondary schools is "to enable the learners to communicate with other users of English either in speech or writing" (1994: 3 and 1996: 5). They explain that "the goal of foreign language teaching is no longer to reach native like proficiency, rather it is directed to towards achieving communicative efficiency, i.e. conveying and understanding meaning in appropriate situations" (1996: 6). ELT in morocco has also undergone a shift of interest and focus from the focus on the teacher, teaching materials and syllabus design to more concern with the learner as an active agent in the process. In this vein, Ouakrime argues that "three elements are essential in the development of a learner-learning-centred approach, the learner, the process of teaching and learning and the context of learning" (1991: 63). In reaction to these recommendations and concern with the learner as active participant in the process of learning and teaching, the writers of the official guidelines state that learners should be equipped with necessary tools to enable them learn by themselves" (1996: 5).

Moreover, the authors of the official guidelines advocate inductive learning as a characteristic of CLT in Morocco. They recommend that "presentation should be inductive [that is], teachers should not present new structures deductively, that is, stating a rule first and then giving examples. Examples of the new structures should relate to meaningful contexts" (1996: 14). They further explain that that "the oral practice of a structure can be considered communicative when the same structure is used in a series of exchanges the purpose of which is to obtain required information" (1996: 15). This concern with CLT does not mean an underestimation of teaching grammar, but it means a focus on meaningful practice and inductive presentation of grammatical structures and rules.

These guidelines advocate the necessity of showing tolerant attitudes towards learners' errors, a practice which would contribute to successful implementation of the communicative approach. In this case, extensive correction of learners' errors would hinder their involvement in classroom message oriented communication and use of language for communicative and functional purposes (Official Guidelines, 1994: 8). To this end the writers of the Official Guidelines (1994 and 1996) suggest a wide range classroom activities and state that the communicative orientation of a methodology "depends on the proportion of time spent on fluency-oriented and acquisition oriented activities" (1994: 7). In sum, ELT teaching in Morocco tends to be communicative in approach.

\section{Objectives and Rational of This Study}

\subsection{The Issue Addressed}

The present study has been concerned with communicative language teaching in Morocco. It addresses the issue 
of theory and practice in the implementation of this approach in this context and aims at studying the differences in the communicative orientation of ELT classrooms in Moroccan secondary schools. More precisely, the first research question is, to what extent are ELT classrooms in Moroccan secondary schools communicatively oriented? Nevertheless, this evaluation of the communicative orientation of these classrooms would be incomplete, unless the restrictions imposed on the implementation of this approach in these contexts are investigated and taken into consideration. Hence, the second research question is what are the major constraints imposed on teaching English for communicative purposes in the context in which this study has been carried out?

These questions are based on the hypothesis that ELT in Morocco is rather communicatively oriented. This hypothesis has been postulated on the basis of the fact that the approach to ELT in Moroccan secondary schools is described as 'communicative' as suggested and recommended by those engaged in English language education in Morocco: teachers, curriculum designers and researchers (see the references cited above). So, it may be deduced that ELT classrooms and the activities that take place there are 'communicative' or at least communicatively oriented. This study aims at confirming or disconfirming this hypothesis through accurate observation and description of these classrooms and evaluating their communicative orientation, using a set of communicative features derived from the literature on CLT and communicative competence and second language research on the topic understudy.

\subsection{The Rationale and Significance of This Study}

Since the very beginning of its emergence in the 1970's, communicative language teaching has gained so much prestige and fashion among curriculum designers and language teachers that any innovation in second and foreign language teaching that seemed to be different from the structural and audio-lingual method has been described as communicative. Consequently, many teachers have come to declare their adherence to CLT, no matter how communicatively oriented their teaching practices are, how effective these practices are in meeting the perceived needs and expectations of their students, and disregarding the restrictions that may be imposed on the translation of this approach into practice. This has given rise to a great deal of dogmatism and confusion among those engaged in second and foreign language education "resulting from the belief that teaching languages is either communicative or not, the dogmatism that has characterized the early days of the development of communicative approaches to language teaching and the haste with which both theoreticians and practicing teachers came to adopt its principles" (Ouakrime, 1993: 33).

Additionally, the source of this confusion is primarily the fact that CLT has been used to refer to a general set of assumptions and innovations about the nature of language and language learning and teaching; hence, the difficulty of defining its principles and boundaries. Moreover, CLT and the development of learners' communicative competence have been considered as a matter of content rather than a methodological matter (Widdowson, 1990). Consequently, more attention has been given to the content of syllabuses such as the functions, situations and topics to be covered, rather than to how to engage learners in interactive language use for different communicative purposes. Furthermore, the advent of CLT broadened the gap between teaching and testing, for while teaching was claimed to be communicative in approach, testing remained audiolingually-based.

The present study focuses on the evaluation of the communicative orientation of ELT classrooms in Moroccan secondary schools and the investigation of the nature of constraints imposed on the implementation of CLT in this context. Its findings should draw teachers' and curriculum designers' attention to the issue that second and foreign language teaching classrooms cannot be described as either communicative or not, in the sense that communication exists in all language classrooms and that the difference between different classroom events and activities with respect to this attribute is the extent to which they are communicatively oriented. They should also draw their attention to the fact that the effectiveness of an approach / method / activity, including CLT, depends on the extent to which it meets the learners' perceived needs and expectations which may come into play, together with other factors, to shape the nature of the classroom environment and communication and facilitate or hinder the implementation of CLT in their contexts.

The findings of this study would help teachers become aware of these issues, namely the degree of consistency between their teaching practices and the principles of CLT on the one hand, and these practices and students expectations and perceptions on the other hand, as well as the nature of restriction imposed on the use of these practices, with the ultimate purpose of reducing the confusion and dogmatism that may result from their attempts to adopt CLT approaches. This evaluative study would help language teachers gain enough information and insights to decide when, where and whether to use communicatively oriented activities. This thesis includes a number of implications that have been drawn from this study as suggestions that curriculum designers and 
teachers could take into consideration to reconsider their teaching practices, teaching materials, classroom activities and patterns of communication to create an atmosphere in the classroom where students could be deliberately engaged in interactive and purposeful communication, a prerequisite for learners' development of communicative competence.

\section{Methodology of Research}

\subsection{The COLT Observation Scheme}

The COLT observation scheme, which stands for Communicative Orientation of Language Teaching, was developed by Allen, Fröhlich and Spada (1984) in order to describe as precisely as possible "some of the features of communication which occur in second language classrooms" (Allen, Fröhlich, \& Spada, 1984: 233). The development of this observation scheme was motivated by the emergence of communicative language teaching, and the issue of theory and practice in the implementation of this approach in second and foreign language teaching classrooms. For example, using the COLT observation scheme in their classroom observation study of the communicative orientation of second language classrooms, Fröhlich, Spada and Allen (1985) distinguished four second language classrooms with respect to the communicative orientation of the classes observed. Another study is that of McKay (1994) who used the COLT observation scheme the first question of her study, "what is the nature of the communicative orientation of the junior secondary French classed observed?" the results obtained distinguished between three types of classes; one class was non-communicatively oriented, that is, highly form-focused; one class was communicatively-oriented, that is, meaning and message-focused, and two classes sat in between. Another important example is Taguchi's (1998) study, where he proposes a classroom research that subscribes more the ethnographic principle of 'observing the whole' whilst utilising the COLT observation scheme as one of the tools" (1998: 6). More importantly, Taguchi used the COLT together with two other data collection techniques - the questionnaire and the interview to incorporate the participants' perspectives in order "to look deeper into the quality and context of classroom interaction" (1998: 6).

In order to address the first question of this study, classroom observation has been used as a data collection technique because the evaluation of the extent to which ELT classrooms in Moroccan secondary schools are communicatively oriented entails that these classrooms need to be systematically observed in order to describe as precisely as possible what happens there. And since this study has been concerned with an essential characteristic of classroom communication, namely its communicative orientation, the COLT observation scheme has been used with some slight modifications within a broader framework which incorporates another component of this evaluation and which constitutes the subject matter of the second question. Therefore, this analysis will focus on the description of the patterns of error treatment, the types of teacher-directed questions and the nature of students' discourse. It will also describe the types and nature of teaching materials, the patterns of classroom interaction, and discourse initiation. It will also describe the form-focused or meaning focused orientation of classroom activities, the nature of the topics communicated, students' nomination and voluntary replies, and noise treatment patterns. This framework for observing and understanding the nature of foreign language classroom communication was used together with audio recording and note taking to capture different aspects of classroom interaction and context. Moreover, the questionnaire was used to collect data from teachers and students whose classrooms were observed in order to support and provide further insights about the data collected through classroom observation.

\subsection{The Two Self-Completion Questionnaires}

In order to answer the second question, two self-completion questionnaires two self-completion questionnaires were designed and distributed to students and teachers whose classrooms were observed. In the first questionnaire, the students were asked questions about on their conceptions of classroom participation, their roles and that of their teachers, as well as their expectations as to what are or are not appropriate teaching/learning activities. The students were also asked to answer questions on their use of the language outside the classroom, their preferred way of preparing for examinations, and what these examinations represent to them. Data was also elicited on their comments on some specific activities that took place in their English classrooms during classroom observation, such as group work, role play, and some patterns of error correction. In brief, the questionnaire was used to elicit information about their conceptions, perceptions, reactions and opinions concerning different aspects of their classroom life and their experience as learners of English as a foreign language.

Another self-completion questionnaire was designed and administered to teachers whose classrooms had been observed. This questionnaire was used to elicit information from teachers about their conceptions of education in general and foreign language education in particular, their experience as teachers of English as a foreign 
language in Morocco, and their perceptions of their role and that of their students as well as their conceptions of classroom participation. It also included items eliciting their comments concerning some specific classroom practices and activities that took place in their classrooms during teaching, and their suggestions for making the process of teaching and learning more effective and their task more successful. More precisely, it was designed to elicit information about teachers' views on the appropriateness of communicative language teaching and the problems they encounter in their attempts to implement communicatively-oriented activities.

The information collected through the questionnaire helped investigate the nature of constraints imposed on the implementation of CLT in the context of ELT in Moroccan secondary schools. It has also helped successful and in-depth interpretation of the data collected through observation. The use of the questionnaire together with classroom observation was meant to incorporate the participants' perspective and ensure triangulation, with the purpose of promoting reliability and validity of the results and probing into the richness and complexities of the classroom context and communication. This is based on the assumption that classroom communication is so rich and complex, in that various variables may come into play to shape the nature of classroom interaction, namely those which relate to the classroom context, teachers' and students' conceptions, expectations and previous teaching and learning experiences.

\subsection{The Classrooms Observed and Respondents}

To answer the first question of this research study - to what extent the ELT classrooms in Moroccan secondary schools are communicatively-oriented - the COLT observation scheme as described above has been used to observe and describe one hundred and twenty English classes over a period of nine weeks. Ten groups of each of the three levels of secondary school students were observed. The classes were observed during March, April and May of the year 2000 and during February 2001. Each group was observed over a period of four sessions/hours. By this time of the academic year, students and teachers have already spent together nearly five months, so that a kind of familiarity is already established, and so that first year students have been learning English for five months. Moreover, such familiarity and a considerable amount of knowledge of English are important in the case of this study which is based on the assumption that the classroom is a social setting and, therefore, the kind of social relationships and interaction prevailing there would indicate whether this environment is or is not conducive to communication and communicative language use.

The groups observed belong to four secondary schools in Fes, three secondary schools in Rabat, two secondary schools in Sefrou and one secondary school in Ghafsai. The city of Fes has been selected for practical reasons. It is also one of the largest cities in Morocco and its population has different regional and geographical backgrounds. The schools selected - Ibn Khaldoun, Ibn Alhaytham, Ibn Hazm, Oum Aimane - are located in different areas of the city, where students certainly have different socio-educational backgrounds. Rabat has been selected, for it is the political capital of the country, where economic, social and political activities are more centralized and where different job opportunities are more or less available. Therefore, students would certainly have different socio-educational backgrounds and perhaps have different reasons and motivations for learning the language from students in Ghafsai, a rural area where students come from a different socio-educational background and where English is the only foreign language taught in Imam Chotaibi, the only secondary school there. Sefrou is a small town where most students have different linguistic backgrounds for the Tamazight language is the mother tongue of a considerable number of them.

\section{Results and Discussion}

\subsection{Results of Classroom Observation}

With respect to the first research question, the results obtained that the data as a whole exhibited a general orientation towards non-communicatively oriented practices. First, the data exhibited the dominance of non-communicatively oriented error treatment practices. Second, the data exhibited a higher frequency of closed patterns of classroom organisation than their open counterparts. It also showed the dominance of display questions and limited/contrived students' discourse over referential questions and students' extended/genuine discourse. Moreover, form-focused/accuracy-oriented activities and non-authentically used material tended to have higher frequency than meaning-focused/fluency-oriented activities and authentically used material. Furthermore, limited/narrow topics and teacher-initiated discourse rather than their broad and students'-initiated counterparts prevailed in the data. Teachers tended to allow students to reply voluntarily without waiting for their nomination and showed a great deal of flexibility in their treatment of students' noise and dealing with noisy students.

It should be noted that some classes were found to be communicatively oriented in spite of the high frequency of display questions and limited/contrived students' discourse. It was observed that this type of questions and 
students' discourse usually took shorter time although frequent in number. For example some activities of five to ten minutes exhibited the occurrence of more than ten display questions, and, therefore, limited/ contrived students' stretches of discourse. On the contrary, one or two referential questions directed and set the ground for some activities of more than fifteen minutes, and, hence, long and long and genuine students' discourse. This fact was considered in the distribution of classes. Moreover, some classes exhibited higher frequency of form-focused activities than meaning-focused activities, but they were group work and pair work in organisation. This is a significant observation in that it reflects a bridge of the gap between the communicative approach and teaching linguistic forms and structures. In practice, it revealed and illustrated the feasibility of adopting a communicatively oriented approach to teaching and learning the formal aspects of language.

Given these observations, the investigation of the frequency of distribution of communicative versus non-communicative features in each of the classes observed revealed a distinction between three sets of classes, communicatively-oriented, non-communicatively-oriented, and in-between classes. The results obtained in this respect are summarised and presented in table1.

Table 1. Comparison between classes with respect to their (non-) communicative orientation

\begin{tabular}{lllll}
\hline & 1 st year & 2nd year & 3rd year & Total \\
\hline Communicatively-oriented classes & $10(25 \%)$ & $16(40 \%)$ & $15(37.5 \%)$ & $41(34.16 \%)$ \\
Non-communicatively-oriented classes & $29(72.5 \%)$ & $21(52.5 \%)$ & $24(60 \%)$ & $74(61.66 \%)$ \\
In-between classes & $01(02.5 \%)$ & $03(07.5 \%)$ & $01(02.5 \%)$ & $05(04.16 \%)$ \\
Total & $40(100 \%)$ & $40(100 \%)$ & $40(100 \%)$ & $120(99.98 \%)$ \\
\hline
\end{tabular}

The results presented in Table 1 indicate that there are seventy-four $(61.66 \%)$ non-communicatively-oriented classes; forty-one $(34.16 \%)$ communicatively-oriented classes; and five $(04.16 \%)$ in-between classes. However, it seems important to note that in spite of the low frequency of communicatively oriented practices and classrooms, the results obtained reveal that important changes have been made towards more communicative language teaching. It indicates that learner-centred communicative language teaching has already started serious competition against the dominance of traditional, frontal, teacher-centred classrooms. Moreover, the dominance of communicative features in forty-one of the classes observed (34.16\%) is relatively high given the current state of communicative language teaching in Morocco and the constraints that were found to impede its implementation in English as a foreign language teaching classrooms in Moroccan secondary schools. The next subsection presents and discusses the results obtained in this respect.

\subsection{Results of the Questionnaire}

It has been found that there is a general tendency among students to perceive the teacher as the central agent of the process of teaching and learning; s/he is generally expected to assume a great deal of responsibility for class management, classroom organization and students' learning and achievement. Students perceive of themselves as generally passive recipients of knowledge which they have to consume in order to pass the exams. It has been also found that in spite of students' recognition of the importance of classroom participation, they generally tend to perceive it as a process of listening to the teacher, answering his/her questions and doing some assignments. However, it should be noted here that in spite of this finding, it may be argued that such conceptions seem to be moving to more learner-centred and communicatively-oriented expectations, manifested in the tendency of an important number of respondents to prefer pair-work and group-work and to consider classroom participation as a process of raising questions and sharing ideas and opinions. They also referred to the teacher as an educator and facilitator and a 'good' student as someone who is active, self-dependent and self-confident and someone who communicates and discusses in class. Many of them considered a student who interrupts the teacher to ask a question or correct a mistake as 'polite' or 'good'. These are some important indicators of this movement among students from traditional and conservative conceptions of learning to more recognition of their role as active participants in the process. If appropriately invested and reinforced, this movement may certainly facilitate the introduction of further communicatively-oriented activities and patterns of classroom organization.

Teachers' conceptions of their role, their students' role, education, the process of teaching and learning in general and communicative language teaching in particular, are largely consistent with the principles of CLT and its implications for second and foreign language teaching classrooms. It has also been found that teachers are generally aware of the difficulty of describing their practices and classrooms as communicative and recognized 
the importance and appropriateness of some non- communicatively-oriented practices for the context where they are operating as teachers of a foreign language. The foreign language context and the formal nature of the classroom and school contexts have been found to bear a negative impact on teachers' attempts to implement more communicatively-oriented activities in their classes, where both them and their students have to conform to certain institutional, administrative and disciplinary routines, and where they have to restrict themselves to certain specific, predetermined and overloaded programmes which they have to finish in a limited amount of time.

Another problem that has been found to restrict the implementation of CLT is the lack of consistency between the assessment procedures used and communicative language teaching. Examinations focus on testing students' grammatical competence, whereas their communicative abilities are not accounted for. This fact explains students' interest in accuracy and exam-oriented activities because they are interested only in what they will be tested on, given the summative nature of assessment procedures in the context of education in Morocco. Moreover, the large class size, lack of adequate and varied teaching materials, equipment and facilities, have been found to restrict teachers' attempts to use more CLT in their context. Additionally, lack of motivation on the part of students and their personal characteristics as well as their low proficiency level in the target language are other problems that teachers encounter in this respect. Furthermore, students' traditional and conservative conceptions have been found to constitute another constraining factor in the implementation of learner-centred communicative language teaching in the context of ELT in Moroccan secondary schools, as underlined by teachers whose classrooms had been observed.

\section{Conclusions and Implications}

\subsection{Conclusions}

In spite of the relatively low frequency of communicatively oriented practices and classrooms, the results obtained suggest that ELT in Moroccan secondary schools has undergone important changes from the dominance of traditional teacher-centred classrooms towards more communicative language teaching. The dominance of communicatively oriented features in forty-four classes $(34.16 \%)$ is relatively high in comparison with the current state of CLT in Morocco and the constraints that have been found to restrict its implementation in this context. Moreover, these findings suggest that the use of CLT in foreign language teaching context is not impossible, but rather feasible. Additionally the finding that a considerable number of form-focused activities were group work and pair work in organisation suggest that the gap between teaching linguistic forms and structures on the one hand and CLT on the other hand can be bridged. This would entail that CLT does not mean the rejection of grammar, but rather the introduction of more student-engaging and meaningful activities in teaching the formal aspects of the target language.

The finding of this study also suggest that the gap between and practice in the implementation of CLT in ELT classrooms in Moroccan secondary schools is evident. While CLT is suggested and recommended by the writers of the official guidelines and generally referred to by the teachers whose classes were observed, the description of these classrooms revealed a tendency for non-communicatively oriented practices to prevail. However, the finding that most teachers did not claim that their classrooms are communicative and that they generally try to make them as communicatively oriented as possible, as well as their reference to different problems that restrict their attempts to ii this regard, it may be argued that there is a great deal of awareness concerning the implementation of this approach and the constraints that limit its use in this context. In addition to this, teachers' recognition of the importance of some audiolingually oriented practices supports this conclusion and suggests that they tend to have critical rather than dogmatic attitudes towards CLT approaches.

Another conclusion that can be deduced from the findings of this study is that is that the emphasis ELT classrooms is on students' grammatical competence, that is, their accurate performance and knowledge of linguistic forms and structures, rather than on their communicative efficiency, that is, their communicative language use abilities. The dominance of direct error treatment practice, display questioning behaviour, limited/contrived students' discourse, form-focused/accuracy-oriented activities, and limited/narrow topics are indicators of this emphasis and greatly shape the nature of communication, in that through these practices teachers maintained control over the content and structure of classroom interaction in this context. The prevalence of these practices reflects a traditional view of classroom communication which is generally reduced to a sequence of teacher-initiation, student(s) response, and teacher-evaluation/feedback (IRE/F). This interactional sequence is an essential characteristic of the traditional audiolingually-oriented classroom interaction and it has been found to be the dominant structure of communication in ELT classrooms in the Moroccan secondary schools classes observed. 
With regard to the finding that direct, extensive and within-utterance error treatment patterns rather than their indirect, selective, and within-utterance counterparts tend to dominate in the data as a whole and in most classes observed, it may be argued that rather non-tolerant attitudes towards students' errors still dominate in ELT classrooms in Moroccan secondary schools. It is a practice and attitude which is inconsistent with the implications of CLT for error treatment behaviour and far from being similar to error treatment practice in foreign and second language use outside the classroom in interaction between native and non-native speakers of the target language. Moreover, given the finding that teachers and students associate this type of error correction pattern with form-focused activities as well as the finding that students tend to feel 'normal' and 'satisfied' when they are corrected by their teachers, it may be argued that that these error treatment conventions are deeply rooted in language teaching classrooms in Moroccan secondary schools where the focus is, accordingly, on students' accuracy rather than fluency.

\subsection{Pedagogical Implications}

Teachers need to develop their students' classroom communicative competence which is an essential is contributing factor to the dynamics of classroom communication, and which is defined in terms of "students" knowledge of and competence in the structural, functional, social, and interactional norms that govern classroom communication" (Johnson, 1995:161). It holds that the classroom context is a specific socio-institutional setting where some particular interactional and socio-cultural conventions are at work. In this regard, Johnson suggests that for teachers to facilitate their students' participation in open patterns of classroom communication and social organization they would need to "make the norms that govern classroom communication both explicit and predictable, create opportunities for students to practice instructional tasks using more exploratory language before being expected to perform in front of the entire class, use of the class meeting to teach small group interaction skills" (1995: 163). This would enhance their creative and productive engagement in classroom interactive communication; otherwise, they could become confused about what is expected of them, or how they are expected to participate.

Teachers need to change their style of leadership in order to create an open space environment and a group climate which would facilitate students' self-motivated and affectionate engagement in the effective accomplishment of classroom interactional events and small-group tasks. In this respect, Cartwright (1970: 325) states that "to change the behaviour of individuals, it may be necessary to change the standards of the group, its style of leadership, and its emotional atmosphere". This suggests the importance of changing the structures of power, communication, and social organization, whereby power, responsibility, and leadership are distributed among the members of the group. Teachers need to assume the role of agents and leaders of change. They also need to successfully manage change and uncertainty, confusion, and resistance it may bring about. To this end, they need to break with the rigid structures of communication and social interaction through the creation of a safe space in the classroom setting.

Finally, the findings if this study suggest that the focus has to be put on promoting teachers' sense of animation of the classroom context in order to be able to create a relaxed and safe atmosphere in this context and make it as open a space as possible where students could feel self-confident and self-dependent and where they could assume some responsibility for conduction classroom interaction and class management. These findings would suggest the importance of training teachers on how to animate rather than control the class. Such training may help them assume the role of ice-breakers in order to make the class a whole group where uninterested sub-groups, unmotivated and shy students could be integrated in the group on the basis of assuming some responsibilities towards their classmates. It may also help them create an atmosphere of familiarity, friendship and mutual trust in the classroom through the maintenance of more group-work, pair-work and class discussion where students could collaborate and cooperate, initiate discourse, and engage in deliberate and purposeful language use for communicative purposes, with the ultimate purpose of promoting their communicative competence and their sense of responsibility and independence. In this way, the negative impact of the formal nature of the classroom and its institutional context, characterised by rigid disciplinary routines and pre-distribution of power and role relationships, could be reduced to its lowest effects.

To this end, teachers' education should aim at encouraging them to engage in reflective practice including action research. Such training should equip teachers to "carry out their own investigations to learn about their immediate teaching contexts" (Bigelow \& Walker, 2004: 14). It would allow them to develop as context sensitive practitioners, and better understand "the peculiarities of everyday life in schools and classrooms" (Cochran-Smith \& Lytle, 1993, 262), and to cope with the complexities of the specific contexts where they operate as teachers of a foreign language. Teachers' engagement in action research would promote their intellectual interest and pedagogical commitment and enhance their awareness of different issues of theory and 
practice in the implementation of language education approaches including learner-centred communicative language teaching. It would also allow them to evaluate the effectiveness of their practices and activities, and better understand the ever-changing reality of their very specific contexts and the nature of classroom communication and context. It would also help them to renovate their knowledge and competencies, refresh their pedagogical expertise, improve their practice, and introduce the necessary and appropriate changes that may help them meet the ever-changing needs and expectation of different groups and generations of students.

\section{References}

Allen, P., Fröhlich, M., \& Spada, N. (1984). The communicative orientation of language teaching: An observation scheme. TESOL Quarterly, 83, 231-252.

Bendouqui, N. (1996). Towards a more systematic teaching of vocabulary. In ELT in Morocco: Perspectives for the 21st Century. Proceedings of the 16th Annual Conference of MATE. Mohammadia: Moroccan Association of Teachers of English.

Brindley, G. P. (1984). Needs analysis and objective setting in the adult migrant education program. Sydney, N.S.W.: Adult Migrant Education Service.

Brindley, G. P. (1989). The role of needs analysis in adult ESL programme design. In R. K. Johnson (Ed.), The Second Language Curriculum. (PP. 63-78) Cambridge: Cambridge University Press. https://doi.org/10.1017/CBO9781139524520.007

Brown, H. D. (1987). Principles of language learning and teaching. Prentice Hall, Englewood Cliffs, NY. https://doi.org/10.3138/cmlr.44.1.181

Brumfit, C.J. and K. Johnson (Eds.). (1979). The communicative approach to language teaching. Oxford: Oxford University Press. https://doi.org/10.2307/3586757

Brumfit, C. (1984). Communicative methodology in language teaching. Cambridge: Cambridge University Press. https://doi.org/10.1017/S0267190500000982

Brumfit, C. (1988). Applied linguistics and communicative language teaching. TESOL Quarterly, 20(4), 709-17. https://doi.org/10.1017/S0267190500000982

Byrness, H. (1987). Getting a better reading: initiatives in foreign language reading instruction. In S. Savignon, \& M. S. Berns (Eds.), Initiatives in communicative language teaching II. Addison-Wesley Publishing Company, Inc.

Cohen, L., \& Manion, L. (1980). Research methods in education. London: Routledge. https://doi.org/10.2307/1175227

Dumitrescu, V. (2000). Authentic materials: Selection and implementation in exercise language training. English Teaching Forum, 38(2), 20-23.

Ellis, R. (1990). Instructed second language development. Oxford: Blackwell.

Ellis, R. (1992). Second language acquisition and language pedagogy. Clevedon: Multilingual Matters. https://doi.org/10.1017/S0272263100010512

Foster, P. (1998). A classroom perspective on the negotiation of meaning. Applied Linguistics, 19(1), 1-23. https://doi.org/10.1093/applin/19.1.1

Fröhlich, M., Spada, N., \& Allen, P. (1985). Differences in the communicative orientation of L2 classrooms. In TESOL Quarterly, 19(1), 27-57. https://doi.org/10.2307/3586771

Hatch, E. (1978). Discourse analysis and second language acquisition. In E. Hatch (Ed.). Second language acquisition. Rowley. Mass.: New bury House. https://doi: 10.12691/education-2-10-15.

Holliday, A. (1994). Appropriate methodology and social context. Cambridge: Cambridge University Press

Johnson, K. E. (1995). Understanding communication in second language classrooms. Cambridge: Cambridge University Press

Kharraf, M., \& Messaoudi, S. (1993). The role of the teacher's guide in EFL Moroccan secondary schools. In Proceedings of the 13th MATE Annual Conference. Ouarzazate: Moroccan Association of Teachers of English (pp. 99-112).

Lightbown, P. (2000). Classroom SLA research and second language teaching. Applied Linguistics, 21(4), 431-462. https://doi.org/10.1093/applin/21.4.431 
Littlewood. (1981). Communicative language teaching. Cambridge: Cambridge University Press. https://doi.org/10.3138/cmlr.38.4.720.

Lynch. T. (1996). Communication in the language classroom. Oxford: Oxford University Press.

McKay, P. (1994). Communicative orientation and language outcomes in Australian junior secondary foreign language classes. Unpublished doctoral dissertation. University of Queensland. Brisbane. Australia.

Nunan, D. (1988). The learner-centred curriculum. Cambridge: Cambridge University Press. https://doi.org/10.1017/CBO9781139524506

Ouakrime, M. (1993). Evaluating classroom teaching: Focus on communication. In Proceedings of the 13th MATE Annual Conference (pp. 33-46). Ouarzazate.

Prabhu, N. S. (1984). Communicative teaching: Communicative in what sense? Paper presented at the 19th Regional Seminar. SEAMEO Regional Language Centre. Singapore.

Royaume du Maroc, Ministère de l'Education Nationale (1994). Documents pedagogiques pour l'anglais. Print Shop: DEDISCO / SALE

Royaume du Maroc, Ministère de l'Education Nationale (1996). Documents pedagogiques pour l'anglais. Print Shop: DEDISCO / SALE.

Swales, J. M. (1993). More discourse analysis in communicative language teaching: More felicity than breakdown? In Proceeding of the 13th MATE Annual Conference (pp. 57-74). Ouarzazate.

Taguchi, K. (1998). The reality of our foreign language classrooms. Research Studies in Progress, 1-13.

Van Lier, L. (1988). The classroom and the language learner. New York: Longman, Inc.

Widdowson, H. G. (1978). Teaching language as communication. Oxford: Oxford University Press.

Widdowson, H. G. (1990). Aspects of language teaching. Oxford: Oxford University Press. https://doi.org/ $10.1017 / \mathrm{S} 0272263100010937$

Appendix 1

\begin{tabular}{|c|c|c|c|c|c|c|c|}
\hline \multicolumn{8}{|c|}{ The COLT Observation Scheme } \\
\hline \multirow{3}{*}{\multicolumn{8}{|c|}{ 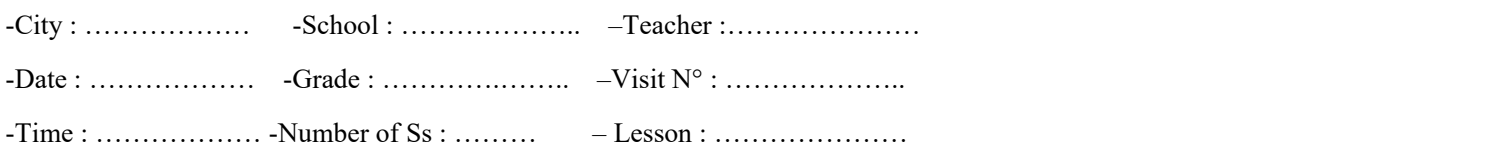 }} \\
\hline & & & & & & & \\
\hline & & & & & & & \\
\hline \multicolumn{8}{|l|}{ Focus on } \\
\hline \multirow{2}{*}{\multicolumn{3}{|c|}{$\begin{array}{l}\text { Type of errors } \\
\text { Error treatment }\end{array}$}} & Pronunciation & grammar & vocabulary & discourse & Function \& socio \\
\hline \multirow{2}{*}{\multicolumn{6}{|c|}{$\begin{array}{l}\text { Error treatment } \\
\text { Neglected/not corrected }\end{array}$}} & & \\
\hline \multirow{2}{*}{\multicolumn{8}{|c|}{$\begin{array}{l}\text { Neglected/ not corrected } \\
\text { Self- corrected }\end{array}$}} \\
\hline & & & & & & & \\
\hline \multicolumn{8}{|l|}{ Peer correction } \\
\hline \multirow{7}{*}{ Teacher correction } & \multirow{2}{*}{$\mathrm{C}$} & Within utteranc & & & & & \\
\hline & & After utterance & & & & & \\
\hline & \multicolumn{2}{|c|}{ Repetition } & & & & & \\
\hline & \multirow{2}{*}{\multicolumn{2}{|c|}{$\begin{array}{l}\text { Metalinguistic } \\
\text { Elicitation }\end{array}$}} & & & & & \\
\hline & & & & & & & \\
\hline & \multicolumn{2}{|c|}{\begin{tabular}{l|l|}
$\mathrm{D} / \mathrm{I}$ & Overt \\
\cline { 2 - 2 }
\end{tabular}} & & & & & \\
\hline & \multirow{2}{*}{\multicolumn{2}{|c|}{$\frac{\text { I Non-overt }}{\text { Referential }}$}} & & & & & \\
\hline \multirow{2}{*}{ Questions } & & & & & & & \\
\hline & \multicolumn{2}{|c|}{ display } & & & & & \\
\hline \multirow{4}{*}{ Nature of discourse } & \multirow{2}{*}{\multicolumn{2}{|c|}{$\begin{array}{l}\text { Limited } \\
\text { Extended }\end{array}$}} & & & & & \\
\hline & & & & & & & \\
\hline & \multicolumn{2}{|c|}{ Contrived } & & & & & \\
\hline & \multicolumn{2}{|c|}{ Genuine } & & & & & \\
\hline \multirow{2}{*}{ Discourse initiation } & \multicolumn{2}{|c|}{ Teacher } & & & & & \\
\hline & \multicolumn{2}{|c|}{ Student } & & & & & \\
\hline \multirow[t]{2}{*}{ Student's replies } & \multicolumn{2}{|c|}{ Named } & & & & & \\
\hline & \multicolumn{2}{|c|}{ Voluntary } & & & & & \\
\hline \multirow{6}{*}{ Structure of interaction } & Teach & class & & & & & \\
\hline & Teach & student & & & & & \\
\hline & Stude & Tass & & & & & \\
\hline & & Pair-work & & & & & \\
\hline & $\mathrm{S} / \mathrm{S}$ & Group work & Same tasks & & & & \\
\hline & & & Di-tasks & & & & \\
\hline & Narro & & & & & & \\
\hline Topic & Limit & & & & & & \\
\hline & Broad & & & & & & \\
\hline Material & Text & & & & & & \\
\hline & Other & Visual & & & & & \\
\hline Noise treatment & Negle & Audio & & & & & \\
\hline
\end{tabular}




\begin{tabular}{|l|l|l|}
\hline & Keep quite/silence SS/ listen & \\
\cline { 2 - 3 } & Stop talking/shut up & \\
\cline { 2 - 3 } & Specifics addressed & \\
\cline { 2 - 3 } & Out ... & \\
\hline Activity & \\
\hline Time & \\
\hline
\end{tabular}

Appendix 2.

\section{THE TEACHER QUESTIONNAIRE}

Thanks for allowing me to attend some of your classes. I would like to ask you some questions on your opinion about English language teaching in Moroccan secondary schools in general and about your English classes in particular.

Only the author of this questionnaire will know the information you provide.

Thank you very much for your help

- Your teaching experience:

1. How long have you been teaching English?

\begin{tabular}{|l|l|}
\hline 1 & $* 1-5$ years \\
\hline 2 & $* 6-10$ years \\
\hline 3 & $*$ More than 10 years \\
\hline
\end{tabular}

2. Learning English is part of your students' education. What does "education" mean to you?

- In your opinion:

3. What are the characteristics of a "good" learner?

4. What do successful teaching and learning depend on?

5. Why don't some students (sometimes the majority) participate?

6. What is the "best" way to treat students' errors?

7. Sometimes, you ask your students to repeat a word, a phrase, or a sentence. Why?

8. When do you usually place your students into small groups?

9. What are the objectives of group work activities?

10. If you were asked this question: which approach or method do you use in your teaching of English, what would your answer be?

11. According to the official guidelines (1994 and 1996) communicative language teaching is recommended with more focus to be put on the students' active participation. From your experience:

12. To what extent is communicative language teaching applicable in the Moroccan (your) context?

13. What kind of activities do you (or don't you) usually use to put this approach into practice?

14. What are the constraints and problems that hinder the successful implementation of these activities in your context?

15. What would you suggest to make English language teaching in Moroccan secondary schools more communicatively oriented?

16. Free comments: (textbooks - exams - equipment - the classroom - context, etc.).

Thank you very much for your help 
Appendix 3.

In this questionnaire, you are asked to answer questions on your opinions about different activities that take place in your English classrooms. The purpose of this questionnaire is to try to understand your perceptions of the teaching techniques and activities used in your English classes. Please, try to answer all the questions honestly.

Only the author of this questionnaire will know the information you provide.

Thank you very much for your help.

Please, circle the number corresponding to your answer.

1. How old are you?

1. between $15-18$

2. between $19-23$

2. Are you

1. female

2. male

3. For how many years have you been studying English?

\begin{tabular}{|l|l|l|l|l|}
\hline One year & Two years & Three years & Four years & Five years \\
\hline 1 & 2 & 3 & 4 & 5 \\
\hline
\end{tabular}

4. What are your reasons and purposes for learning English?

5. Do you think that teaching English in Morocco is

1 . necessary

Please, justify your answer.

2. unnecessary

6. Do you find your English classes

1. enjoyable

2. boring

3. neither of them

Please, justify your answer.

7. How easy or difficult do you find your English lessons?
1 . very difficult
2. difficult
3. average
4. easy
5. very easy

8. Which areas do you find difficult?

\begin{tabular}{|l|l|l|l|l|}
\hline 1. grammar & 2.vocabulary & 3.pronunciation & 4.communication & 5.writing \\
\hline
\end{tabular}

Please, explain why you find this area difficult?

9. Do you think the amount of time given to your English sessions is?

1. enough

2. more than enough

3. not enough

10. Do you understand your teacher when he/she is explaining?

1. yes

2. no

Please, justify your answer

11. What could you suggest to make teaching English in your classroom better?

Or what could your teachers do to make you understand better?

12. During my attendance to your English classes, I observed that sometimes your teacher places you in groups and tells you to discuss the answers with your friends in the group. In your opinion, why does he or she do this?

13. Do you like doing an exercise

1. individually

2. with your neighbor

3. in a group of more than two students

Please, justify your answer

14. I have also observed that sometimes your teacher asks you to repeat a word, a phrase, or a sentence. Why do you think she or he does this?

15. I have also observed that during discussion and communication, the teacher does not correct your mistakes and helps you to talk as much as possible but when you have a lesson on pronunciation, vocabulary or grammar, he or she corrects a great number of your mistakes and asks you to repeat the correct forms. In your opinion, why does she or he do this? 
And what are you feelings when she or he corrects your mistakes?

\begin{tabular}{|l|l|l|l|}
\hline 1. normal & 2.satisfied & 3.embarrassed & 4.dissatisfied \\
\hline
\end{tabular}

16. Do you participate in class?

\begin{tabular}{|l|l|l|l|l|}
\hline 1. always & 2.often & 3.sometimes & 4.rarely & 5.never \\
\hline
\end{tabular}

Please, justify your answer.

17. What does participation in class mean to you?

1. To listen quietly and take notes

2. To answer the teacher's questions

3. To raise questions and share ideas during discussion

4. To speak for a long time

18. Do you think that a student who interrupts the teacher to ask a question or correct an error is:
1. impolite
2. Polite
3. good
4. bad

Please, justify your answer:

19. In your opinion, what is the role of the teacher?

1. To help students learn the language.

2. To control the classroom

3. To provide students with the knowledge they need.

4. To educate students

5. To facilitate students' difficulties in learning English

6. Any other answer.

20. What is a "good" student for you?

21. What images come to you when you hear the word "teacher"?

1. Someone who knows the answers

2. Someone who asks questions

3. Someone who stands in front of the class and tells the students what they need to know

4. Someone who says "hurry up" "have you finished" "be quite"

5. Someone who stands in the middle of the class as a member of the class.

22. What is a "good" teacher for you?

23. Do you speak English outside the classroom?

1. often

2. sometimes

3.rarely

4. never

Why, where and with whom?

24. What does "a school" mean to you?

1. Attendance sheet

2. Exams

3. Meeting friends

4. Success and failure

5. Exercises and homework obligations

6. A place where students are educated

7. A place where good students are selected

25. Briefly describe the difference between your behavior (the way you talk and act) at home, on your way to school and when you are at school

26. Please describe the best way for you to prepare for your exam in English 


\section{Copyrights}

Copyright for this article is retained by the author(s), with first publication rights granted to the journal.

This is an open-access article distributed under the terms and conditions of the Creative Commons Attribution license (http://creativecommons.org/licenses/by/4.0/). 